\title{
Thermal responses of periodical cicadas: within and between brood parity (Hemiptera: Cicadidae: Magicicada spp.)
}

This article was published in the following Dove Press journal:

Open Access Insect Physiology

3 October 2009

Number of times this article has been viewed

\author{
Allen F Sanborn' \\ James E Heath ${ }^{2}$ \\ 'Department of Biology, Barry \\ University, Miami Shores, FL, USA; \\ ${ }^{2}$ Department of Physiology, University \\ of Illinois, Urbana, IL, USA
}

\begin{abstract}
Measurements of the thermal responses of insects have been used to determine thermal adaptation to various environments. We have compared the thermal responses (minimum flight temperature, maximum voluntary tolerance temperature, and heat torpor temperature) of five periodical cicada species (Magicicada septendecim, M. cassinii, M. septendecula, M. tredecassini, and M. neotredecim) to test the hypothesis that the thermal responses are similar within and between broods due to the similar environmental conditions experienced by each brood. Cicadas of Brood XIII were collected in 1973, 1990, and 2007 in northern Illinois. Comparisons are made to data from specimens collected during the 1987 Brood X and the 1998 Brood XIX emergences in southeastern Tennessee, and the 1989 Brood XXIII emergence in central Illinois. The maximum voluntary tolerance (an upper thermoregulatory temperature) and the heat torpor temperatures do not differ between the five species examined. Only one species (M. neotredecim) differs statistically in the minimum flight temperature from the other species and one species pair (M. septendecula and M. neotredecim) differs in heat torpor temperature. There were a few examples of between brood statistical differences in the minimum flight temperature (M. tredecassini) and heat torpor temperature (M. tredecassini, M. cassinii) and one species pair differed significantly in heat torpor temperature. The data show that thermal responses generally do not change statistically in different emergences of the same brood or over large portions of a species range and the thermal responses of all species are similar.
\end{abstract}

Keywords: Magicicada, thermal responses, temperature adaptation, cicada

\section{Introduction}

Temperature influences the ability of animals to survive because it alters the rate of chemical reactions necessary to maintain living systems and thus sets limits for the viability of species. The daily temperature changes faced by terrestrial animals has meant animal cells cannot function efficiently at every ambient temperature potentially experienced during the day. Diurnal animals generally thermoregulate in order to maintain their body temperature at a level where physiological processes will occur at maximal efficiency despite the changes to ambient temperature over the course of a day. ${ }^{1}$ The various habitats used by animals mean that individual species must adapt to specific thermal environments in order to survive.

The thermal responses of insects have been used as a measure of thermal adaptation to specific environments. ${ }^{2}$ Cicadas have been a model system for this type of research as their relatively large body size allowed body temperatures to be measured accurately. The first thermal adaptation study of cicadas investigated a periodical cicada, ${ }^{3}$ but thermal data for a large number of species from North America, South America, Africa, and Australia have since been published. ${ }^{2,4-20}$
Correspondence: Allen F Sanborn

Department of Biology, Barry University, I I 300 NE Second Avenue, Miami Shores, FL 33161-6695, USA

$\mathrm{Tel}+\mathrm{I} 3058993219$

Fax + I 3058993225

Email asanborn@mail.barry.edu 
The periodical cicadas are a group of seven cicada species that have either a 17-year (Magicicada septendecim [L.], M. cassinii [Fisher], M. septendecula Alexander and Moore) or 13-year (M. tredecim [Walsh and Riley], M. tredecassini Alexander and Moore, M. tredecula Alexander and Moore, M. neotredecim Marshall and Cooley) life cycle. The individual year groups are categorized into Broods numbered I-XVII for the 17-year broods and XVIII-XXX for 13-year broods. ${ }^{21}$ Each brood emerges at regular intervals in particular locations (see reviews of periodical cicada biology ${ }^{22,23}$ ), but the species extend over large regions of the eastern United States. The 17-year species generally have a more northern distribution than the 13-year species.

Expansive distribution of the periodical cicadas provides an opportunity to investigate regional influences on thermal adaptation. Since thermal adaptation has been shown to be genetically determined in other insects, ${ }^{24-28}$ there is a possibility that local changes in gene frequency have led to differences in the thermal responses over the range of individual species. We studied individual species (M. septendecim, M. cassinii, M. septendecula, $M$. tredecassini, and $M$. neotredecim) from different broods as well as three consecutive emergences of Brood XIII to test the hypothesis that the thermal responses are similar within and between broods due to the similar environmental conditions experienced by each brood.

\section{Materials and methods}

Brood XIII Magicicada emergences were studied in Raccoon Grove ( $\left.41^{\circ} 23^{\prime} 35^{\prime \prime} \mathrm{N} 87^{\circ} 45^{\prime} 21^{\prime \prime} \mathrm{W}\right)$, Will County, Illinois in 1973 and the same collecting sites in Des Plaines $\left(42^{\circ} 00^{\prime}\right.$ $\left.22^{\prime \prime} \mathrm{N} 87^{\circ} 51^{\prime} 52^{\prime \prime} \mathrm{W}\right)$ and Brookfield ( $41^{\circ} 49^{\prime} 59^{\prime \prime} \mathrm{N} 87^{\circ}$ $\left.50^{\prime} 02^{\prime \prime} \mathrm{W}\right)$, Cook County, Illinois during both 1990 and 2007. Brood X specimens were captured south of Walland ( $\left.35^{\circ} 42^{\prime} 01^{\prime \prime} \mathrm{N} 83^{\circ} 48^{\prime} 13^{\prime \prime} \mathrm{W}\right)$, Blount County, Tennessee (M. septendecim) or in Knoxville ( $35^{\circ} 52^{\prime} 39^{\prime \prime} \mathrm{N} 84^{\circ} 02^{\prime}$ $30^{\prime \prime} \mathrm{W}$ ), Knox County, Tennessee (M. cassinii) in 1987. Brood XXIII specimens were collected in Clinton Lake ( $40^{\circ} 08^{\prime} 54^{\prime \prime}$ N $\left.88^{\circ} 52^{\prime} 39^{\prime \prime} \mathrm{W}\right)$, DeWitt County, Illinois. Finally, Brood XIX specimens were collected in Friendsville ( $35^{\circ} 45^{\prime} 07^{\prime \prime}$ $\left.\mathrm{N} 84^{\circ} 07^{\prime} 30^{\prime \prime} \mathrm{W}\right)$, Blount County, Tennessee. The data published $^{3}$ on $M$. cassinii from Brood IV were collected at Dirty Creek (35 26 47" N 95 06' 07" W), near Webbers Falls, Muscogee County, Oklahoma.

The thermal responses were determined using the methodology outlined in the original cicada thermal response studies. ${ }^{3,4}$ Specimens were transported to the laboratory in a cardboard container with a moist paper towel in a cooler in an effort to minimize metabolism until experiments could be performed. Experiments were generally performed during the afternoon or evening of the day of capture.

Body temperature $\left(\mathrm{T}_{\mathrm{b}}\right)$ was measured in the laboratory with either a telethermometer and a 26-gauge hypodermic thermistor probe (1973 data) or a Physitemp Model BAT-12 digital thermocouple thermometer with a type MT 29/1 29 gauge hypodermic microprobe copper/constantan thermocouple accurate to $\pm 0.1{ }^{\circ} \mathrm{C}$ and a time constant of $0.15 \mathrm{~s}^{-1}$ (Physitemp Instruments, Inc., Cliffon, NJ, USA). All thermocouple probes were calibrated to a National Institute of Standards and Technology thermometer to insure accuracy. Deep $T_{b}$ was measured by inserting a probe midway into the dorsal mesothorax. Specimens were handled only by the wings prior to insertion of the thermocouple to prevent conductive heat transfer between the insect and experimenter. Each $T_{b}$ was recorded within $5 \mathrm{~s}$ of the animals performing the desired behavior.

Prior to beginning the thermal experiments, specimens were cooled to torpor by placing them in a container above ice or in a refrigerator. Specimens were then tossed 1-2 m into the air, warming passively, until they made a controlled flight or landing, after which their $T_{b}$ was measured. This $T_{b}$ is the minimum flight temperature (MFT) and represents the lowest $\mathrm{T}_{\mathrm{b}}$ of fully coordinated flight activity. Individual specimens were placed under a heat lamp to determine the maximum voluntary tolerance (MVT) or shade-seeking temperature. When the animal walked or flew from the heat source, its $\mathrm{T}_{\mathrm{b}}$ was measured. The MVT is an upper thermoregulatory temperature representing the $T_{b}$ when thermoregulation takes precedence over other behaviors. ${ }^{29}$ The final $\mathrm{T}_{\mathrm{b}}$ to be recorded was the heat torpor temperature (HTT). HTT was determined by heating an insect with the heat lamp within a paper container until it stopped moving. The procedure is nonlethal as animals recover motor control within a few minutes as they cool passively. The HTT represents the upper limit of activity and may be an ecologically lethal $\mathrm{T}_{\mathrm{b}}$ since the animals are no longer able to move to avoid any continued increase in $T_{b}$. MFT and HTT delineate the $T_{b}$ range within which a species is fully active as cicadas are torpid outside of this $\mathrm{T}_{\mathrm{b}}$ range.

Statistical analyses were performed using InStat 3.0a for the Macintosh (GraphPad Software, San Diego, CA). Statistical significance is considered to be $\alpha=0.05$ for all tests. Statistics are reported as mean \pm standard deviation.

\section{Results}

The thermal responses for all species and broods within species are summarized in Table 1. No data for the MFT of the 
Table I Thermal responses of Magicicada species. Minimum flight temperatures are not provided for the I 973 and I 987 emergences due to problems with the experiments (see Results). The data for Brood IV M. cassinii are provided for comparative purposes but were not used to determine the species averages or in the statistical analyses. The Brood IV data do not differ from the average determined for M. cassinii (MFT $\mathrm{t}=0.0613$, d.f. $72, P=0.95 \mathrm{I} 3$; MVT $\mathrm{t}=1.698$, d.f. II9, $P=0.092 \mathrm{I}$ ). Complete statistical analyses are provided in the text

\begin{tabular}{|c|c|c|c|c|}
\hline Species & Brood emergence & $\begin{array}{l}\text { Minimum flight } \\
\text { temperature }\left({ }^{\circ} \mathrm{C}\right)\end{array}$ & $\begin{array}{l}\text { Maximum voluntary } \\
\text { tolerance temperature }\left({ }^{\circ} \mathrm{C}\right)\end{array}$ & $\begin{array}{l}\text { Heat torpor } \\
\text { temperature }\left({ }^{\circ} \mathrm{C}\right)\end{array}$ \\
\hline \multirow[t]{10}{*}{ M. septendecim } & & $20.2 \pm 1.50^{b}$ & $33.3 \pm 2.76$ & $42.5 \pm 1.48$ \\
\hline & & $\mathrm{n}=52$ & $\mathrm{n}=88$ & $\mathrm{n}=76$ \\
\hline & Brood X & & $33.6 \pm 2.82$ & $43.2 \pm 1.61$ \\
\hline & 1987 & & $\mathrm{n}=12$ & $\mathrm{n}=12$ \\
\hline & Brood XIII & & $32.8 \pm 3.29$ & $41.8 \pm 1.46$ \\
\hline & 1973 & & $\mathrm{n}=20$ & $\mathrm{n}=10$ \\
\hline & 1990 & $20.4 \pm|.5|$ & $33.3 \pm 2.69$ & $42.4 \pm 1.26$ \\
\hline & & $\mathrm{n}=38$ & $\mathrm{n}=40$ & $\mathrm{n}=38$ \\
\hline & 2007 & $19.5 \pm 1.34$ & $33.6 \pm 2.29$ & $42.8 \pm 1.73$ \\
\hline & & $\mathrm{n}=14$ & $\mathrm{n}=16$ & $\mathrm{n}=16$ \\
\hline \multirow[t]{13}{*}{ M. cassinii } & & $20.8 \pm 1.78^{c}$ & $33.0 \pm 2.55$ & $42.5 \pm 1.59$ \\
\hline & & $\mathrm{n}=64$ & $\mathrm{n}=107$ & $\mathrm{n}=92$ \\
\hline & Brood X & & $32.4 \pm 2.70$ & $41.7 \pm 1.978$ \\
\hline & 1987 & & $\mathrm{n}=20$ & $\mathrm{n}=20$ \\
\hline & Brood XIII & & $33.0 \pm 2.75$ & $42.4 \pm 0.90$ \\
\hline & 1973 & & $\mathrm{n}=23$ & $\mathrm{n}=10$ \\
\hline & 1990 & $20.7 \pm 1.71$ & $33.2 \pm 2.45$ & $42.6 \pm 1.48$ \\
\hline & & $\mathrm{n}=4 \mathrm{I}$ & $\mathrm{n}=4 \mathrm{I}$ & $\mathrm{n}=39$ \\
\hline & & $20.9 \pm 1.95$ & $33.3 \pm 2.49$ & $43.1 \pm 1.36^{g}$ \\
\hline & 2007 & $\mathrm{n}=23$ & $\mathrm{n}=23$ & $\mathrm{n}=23$ \\
\hline & Brood IV & & & \\
\hline & 1964 & $20.9 \pm 2.84$ & $31.8 \pm 2.51$ & \\
\hline & & $\mathrm{n}=10$ & $\mathrm{n}=14$ & \\
\hline \multicolumn{5}{|l|}{ M. septendecula } \\
\hline & Brood XIII & & & \\
\hline & & $20.6 \pm 2.24^{d}$ & $32.6 \pm 2.01$ & $43.0 \pm 1.22^{h}$ \\
\hline & 2007 & $\mathrm{n}=19$ & $n=21$ & $\mathrm{n}=20$ \\
\hline \multicolumn{5}{|l|}{ M. neotredecim } \\
\hline & Brood XXIII & & & \\
\hline & & $18.0 \pm 1.09^{b, c, d, e}$ & $31.2 \pm 1.62$ & $41.4 \pm 1.45^{h}$ \\
\hline & 1989 & $\mathrm{n}=10$ & $\mathrm{n}=10$ & $\mathrm{n}=10$ \\
\hline \multirow[t]{6}{*}{ M. tredecassini } & & $20.1 \pm\left. 2.4\right|^{\mathrm{e}}$ & $33.3 \pm 1.83$ & $41.8 \pm 1.66$ \\
\hline & & $\mathrm{n}=25$ & $\mathrm{n}=24$ & $\mathrm{n}=25$ \\
\hline & Brood XXIII & $18.4 \pm 1.48^{f}$ & $33.0 \pm 1.53$ & $40.4 \pm 1.07^{i}$ \\
\hline & 1989 & $\mathrm{n}=10$ & $\mathrm{n}=10$ & $\mathrm{n}=10$ \\
\hline & Brood XIX & $21.2 \pm 2.29^{f}$ & $33.5 \pm 2.05$ & $42.7 \pm 1.32^{i}$ \\
\hline & 1998 & $\mathrm{n}=15$ & $\mathrm{n}=14$ & $\mathrm{n}=15$ \\
\hline
\end{tabular}

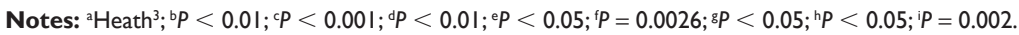

1973 M. septendecim are included because the experiments could not be performed on the day of capture. This meant the animals were kept in a cold environment overnight decreasing their willingness to fly during the experiments the next morning. Similarly, no MFT data are provided for the 1987 emergence of $M$. septendecim as the refrigerator in which the specimens were stored prior to experimentation was so cold that the animals would not fly after being removed and rewarmed. Both groups behaved normally with respect to the MVT and HTT experiments. 
Comparisons of the data from the 1973, 1990, and 2007 emergence of Brood XIII M. septendecim show no statistical difference between MFT $(\mathrm{t}=1.918$, d.f. $=50, P=0.0608)$, MVT (ANOVA F $=0.3907$, d.f. $=2,73, P=0.6780$ ), or HTT (ANOVAF $=1.495$, d.f. $=2,61, P=0.2324)$ (Figures $1-3$ ). The same trends are seen for the MFT $(\mathrm{t}=0.0286$, d.f. $=62$, $P=0.7968$ ), MVT (ANOVA $\mathrm{F}=0.05124$, d.f. $=2,84$, $P=0.9501$ ), and HTT (ANOVA $\mathrm{F}=1.569$, d.f. $=2$, $69, P=0.2157$ ) for $M$. cassinii collected from Brood XIII.

The same lack of statistical differences is found when Brood X data are added to the analysis. The data are not significantly different for M. septendecim (MFT $\mathrm{t}=1.918$, d.f. $=50, P=0.0608$, MVT ANOVA $\mathrm{F}=0.3274$, d.f. $=3,84, P=0.8056$, or HTT ANOVA $\mathrm{F}=2.066$, d.f. $=3,72, P=0.1208)$ or $M$. cassinii $($ MFT $\mathrm{t}=0.0286$, d.f. $=62, P=0.7968$, or MVT ANOVA F $=0.5334$, d.f. $=3$, 103, $P=0.6604$ ). Only the HTT (ANOVA F $=3.413$, d.f. $=3,88, P=0.0209$ ) shows a significant difference in $M$. cassinii. A Tukey-Kramer multiple comparison test shows the 1987 and $2007(\mathrm{q}=4.498, P<0.05)$ are the only data sets to show a statistical difference for $M$. cassinii.

The data for M. tredecassini show significant differences between Broods XIX and XXIII for MFT ( $\mathrm{t}=3.379$, d.f. $=23$, $P=0.0026)$ and $\operatorname{HTT}(\mathrm{t}=4.528$, d.f. $=23, P=0.002)$.

\section{Magicicada minimum flight temperature}

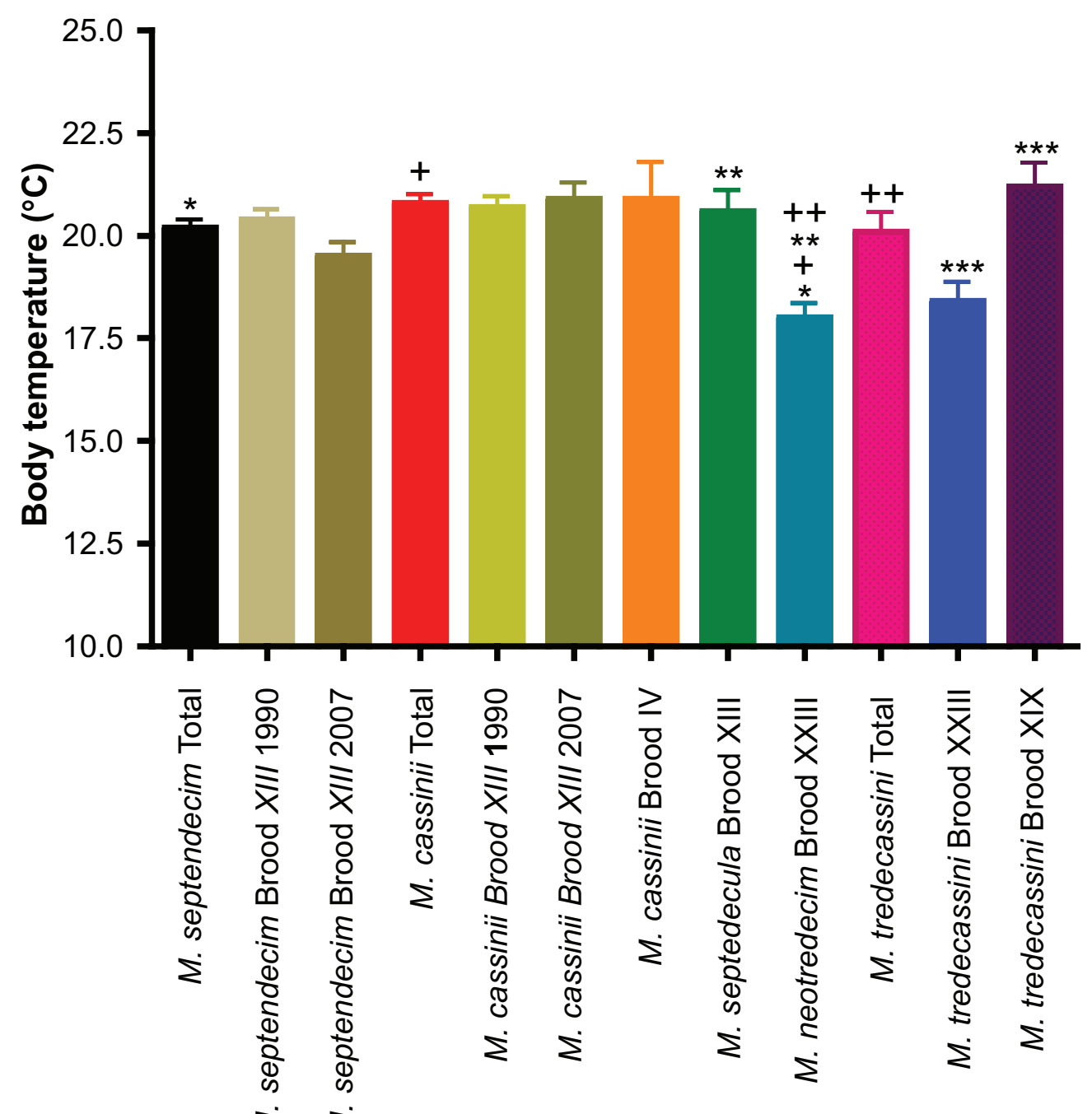

\section{Species/Brood}

Figure I Minimum flight temperature determined for the periodical cicadas. Magicicada neotredecim differs significantly from the remaining species and the two broods of M. tredecassini differ from each other. Complete statistical analysis is provided in the text.

Notes: ${ }^{*}{ }^{* * P}<0.01{ }^{+} P<0.001 ;{ }^{++} P<0.05$. ${ }^{* * * P}=0.0026$ 


\section{Magicicada maximum voluntary tolerance temperature}

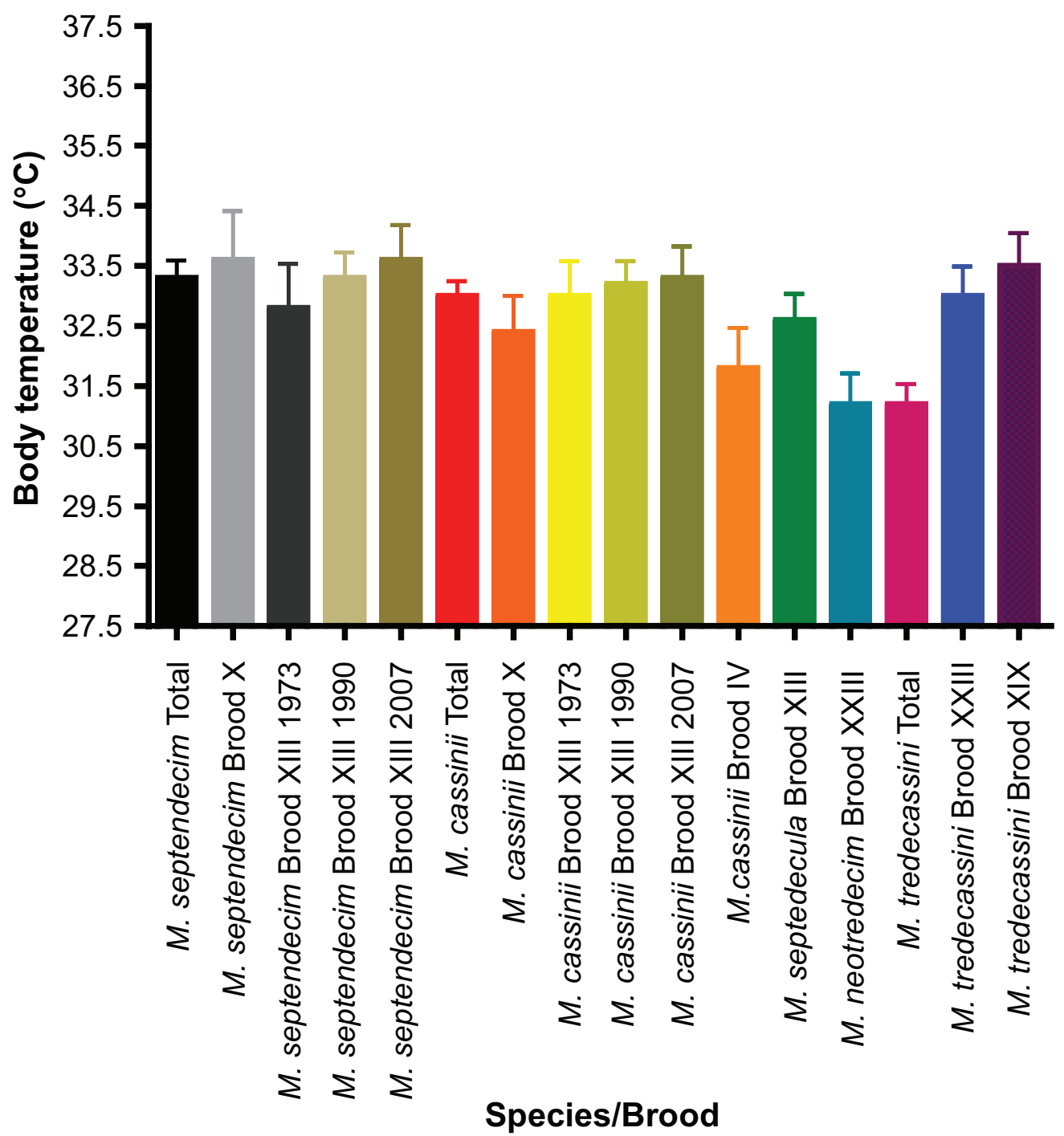

Figure 2 Maximum voluntary tolerance temperature determined for the periodical cicadas. There are no statistically significant differences in the means determined within or between broods or between species.

However, the MVT data did not differ significantly between broods $(\mathrm{t}=0.6748$, d.f. $=22, P=0.5069)$.

When comparing the mean values for all species studied, the MFT data show the greatest variability (ANOVA $\mathrm{F}=5.430$, d.f. $=4,165, P=0.0004)$. A Tukey-Kramer multiple comparison test shows MFT of M. neotredecim shows significant differences from $M$. septendecim $(\mathrm{q}=4.877, P<0.01), M$. septendecula $(\mathrm{g}=5.192$, $P<0.01), M$. cassinii $(\mathrm{q}=6.369, P<0.001)$, and M. tredecassini $(\mathrm{q}=4.335, P<0.05)$. The corrected Bartlett statistic $(12.872, P=0.0119)$ suggests differences in the standard deviations of the MFT means are different so nonparametric test was then performed. The Kruskal-Wallis test $(\mathrm{KW}=18.579, P=0.0010)$ also suggests there are differences between means. The Dunn's multiple comparisons test suggests that $M$. neotredecim differs from M. septendecim $(P<0.05), M$. septendecula $(P<0.05)$, and $M$. cassinii $(P<0.001)$. The MVT (ANOVA F $=1.900$, d.f. $=4,245, P=0.1111)$ shows no significant differences between species. The HTT (ANOVA F $=3.153$, d.f. $=4,218$, $P=0.0152$ ) suggests significant differences between species. A Tukey-Kramer multiple comparison test suggests only the HTT of $M$. neotredecim shows a significant difference from $M$. septendecula $(\mathrm{q}=3.928, P<0.05)$.

\section{Discussion}

The parity within and between groups suggests that all species are adapted to similar thermal conditions. This is not 


\section{Magicicada heat torpor temperatures}

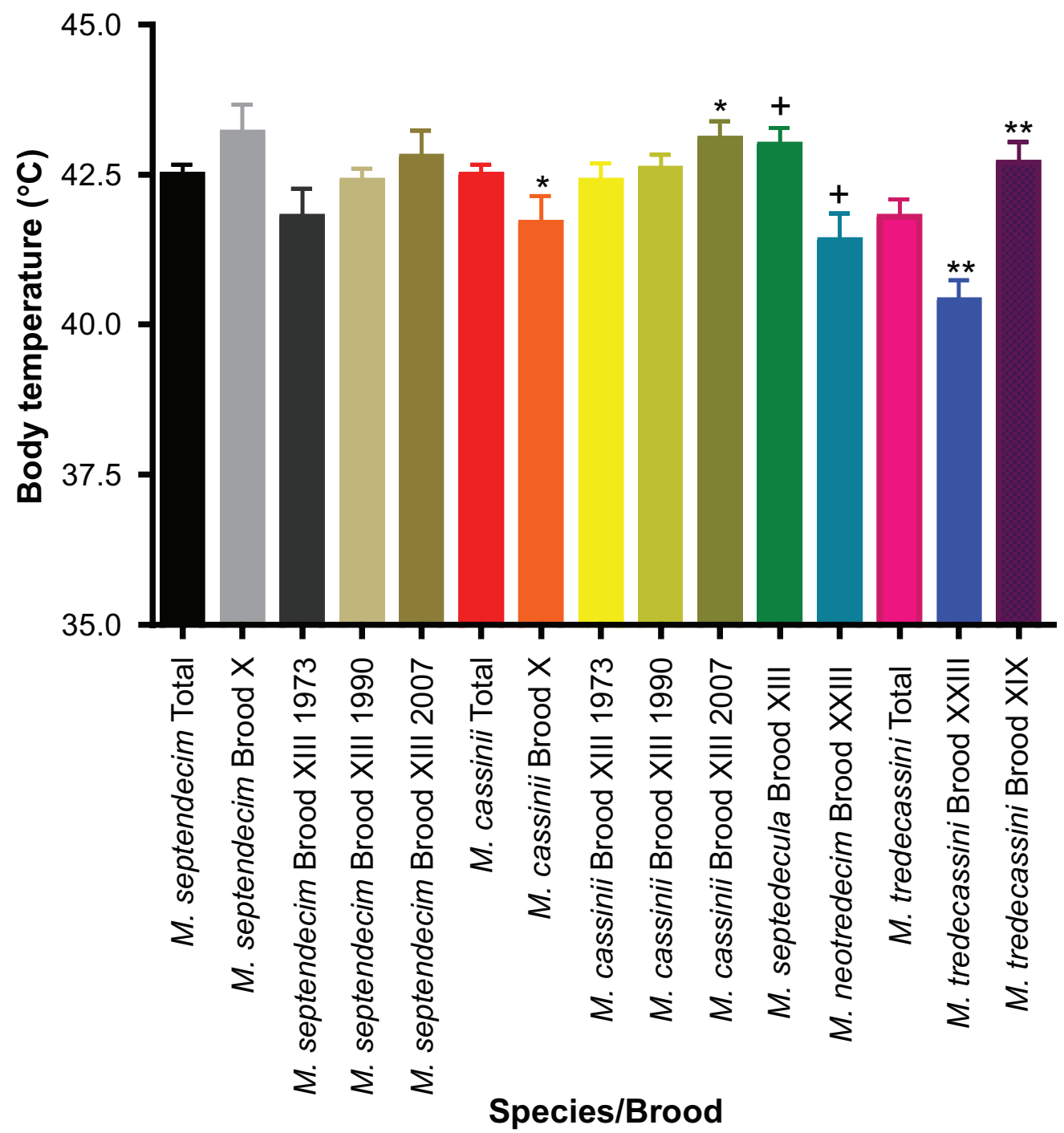

Figure 3 Heat torpor temperature determined for the periodical cicadas. The Brood X and the 2007 Brood XIII data differ significantly within M. cassinii as do the data for M. tredecassini Broods XXIII and XIX. The only species data to differ significantly are the data species for M. septendecula differ from M. neotredecim. Complete statistical analysis is provided in the text.

Notes: ${ }^{*}{ }^{+} P<0.05 ; * * P=0.002$.

surprising since the 17-year and 13-year species of individual broods have evolved to emerge synchronously. The survival benefits of the periodic and short-term emergences are only sustained if all individuals emerge in a brood emerge synchronously. The results are supported by the thermal responses of other closely related cicada species having been shown to be similar as well. . $^{10,11,13,14,16}$

The MFT is the thermal response that showed statistically significant differences within and between broods or species. MFT does not seem to be dependent on the environment in which a species lives. Instead, MFT is dependent on the morphology of the flight system. ${ }^{30}$ The variability in MFT values is probably the result of the morphological influence of individual species on MFT. The MFT of M. neotredecim is significantly different from most other species suggesting that there is a difference in the flight system. However, determining when a specimen reaches the MFT is the most subjective of the thermal response experiments. This may be partially responsible for the differences in MFT values for the different broods of $M$. tredecassini.

The MVT was consistent both within and between broods as well as between species. The thermal environment to which each brood will be exposed during an emergence will be consistent as well. Similar MVT would be expected as all 
species have the same thermal environment to manipulate in order to regulate $T_{b}$. Adapting to function more efficiently at higher or lower $\mathrm{T}_{\mathrm{b}}$ would put ectothermic species like the periodical cicadas at a disadvantage in terms of maintaining activity. Fewer hours of activity would lead to less time to find a potential mate, decreasing the reproductive potential of individuals that are adapted to the higher or lower $\mathrm{T}_{\mathrm{b}}$ for peak activity, which would selecting against different MVT values in the different species. Combining these data with the MFT and MVT data in Heath ${ }^{3}$ (which do not differ significantly from the data provided here, MFT $\mathrm{t}=0.0613$, d.f. $72, P=0.9513 ;$ MVT t $=1.698$, d.f. 119 , $P=0.0921)$, the thermal responses of $M$. cassinii are the same from Oklahoma to northern Illinois to southeastern Tennessee.

The similarity in HTT within and between broods and species would be expected for the same reasons as similarity in the MVT. The only difference found was between $M$. septendecula and $M$. neotredcecim and the two broods of $M$. tredecassini. The statistical significance of the difference between $M$. septendecula and M. neotredecim is barely significant $(\mathrm{q}=3.928$ with significance if $\mathrm{q}>3.900)$ and may be the result of one low value determined during the experiments (significance disappears if the datum is eliminated from the analysis). The differences observed in the M. tredecassini HTT are more difficult to explain but may be related to the age of the population in 1989. There were many dead animals in the habitat when the experimental group was collected so the low HTT may be a result of deterioration of function with aging of the population. Similarly, the one pair of M. cassinii that showed a statistical difference in HTT included the 1987 group which may have been altered due to the fact that these specimens were nearly frozen prior to experimentation. The extreme cold may have weakened the group producing the lower HTT.

Thermal adaptation has been shown to be genetically determined in insects other than cicadas. ${ }^{24-28}$ The similarities of the thermal responses of periodical cicadas suggest that they are also genetically determined and maintained within populations of cicadas as well. The long life cycle of periodical cicadas would mean that these species would not be able to adapt quickly to changing climate as has been seen in other insects. ${ }^{24}$

\section{Acknowledgments}

Polly Phillips assisted with data collection in 1990. Russell and Mary Ann Sanborn (1987 and 2007) and Mark Bahlenhorst (1990) provided logistical support and space where experiments could be performed. The authors report no conflicts of interest in this work.

\section{References}

1. Sanborn AF. Cicada thermoregulation (Hemiptera, Cicadoidea). Denisia. 2002;4:455-470.

2. Heath JE, Hanagan JL, Wilkin PJ, Heath MS. Adaptation of the thermal responses of insects. Am Zool. 1971;11:147-158.

3. Heath JE. Temperature responses of the periodical "17-year" cicada, Magicicada cassini (Homoptera, Cicadidae). Am Midl Nat. 1967; 77:64-67.

4. Heath JE, Wilkin PJ. Temperature responses of the desert cicada, Diceroprocta apache (Homoptera, Cicadidae). Physiol Zool. 1970; 43:145-154.

5. Heath JE, Wilkin PJ, Heath MS. Temperature responses of the cactus dodger, Cacama valvata (Homoptera, Cicadidae). Physiol Zool. 1972;45:238-246.

6. Heath MS. Temperature requirements of the cicada Okanagana striatipes beameri: A study from Flagstaff, Arizona. Plateau. 1972;45:31-40.

7. Sanborn AF, Heath JE, Heath MS. Thermoregulation and evaporative cooling in the cicada Okanagodes gracilis (Homoptera: Cicadidae). Comp Biochem Physiol Physiol. 1992;102A:751-757.

8. Sanborn AF, Heath JE, Heath MS, Noriega FG. Thermoregulation by endogenous heat production in two South American grass dwelling cicadas (Homoptera: Cicadidae: Proarna). Fla Entomol. 1995; 78:319-328

9. Sanborn AF, Heath MS, Heath JE, Noriega FG. Diurnal activity, temperature responses and endothermy in three South American cicadas (Homoptera: Cicadidae: Dorisiana bonaerensis, Quesada gigas, and Fidicina mannifera). J Therm Biol. 1995;20:451-460.

10. Sanborn AF, Phillips PK. Thermal responses of the Diceroprocta cinctifera species group (Homoptera: Cicadidae). Southwest Nat. 1996;41:136-139.

11. Sanborn AF. Comparative thermoregulation of sympatric endothermic and ectothermic cicadas (Homoptera: Cicadidae: Tibicen winnemanna and Tibicen chloromerus). J Comp Physiol A. 2000;186:551-556.

12. Sanborn AF, Maté S. Thermoregulation and the effect of body temperature on call temporal parameters in the cicada Diceroprocta olympusa (Homoptera: Cicadidae). Comp Biochem Physiol Physiol. 2000;125A:141-148.

13. Sanborn AF, Phillips PK. Re-evaluation of the Diceroprocta delicata species complex (Homoptera: Cicadidae). Ann Entomol Soc Am. 2001;94:159-165.

14. Sanborn AF, Breitbarth JH, Heath JE, Heath MS. Temperature responses and habitat sharing in two sympatric species of Okanagana (Homoptera: Cicadoidea). West N Am Nat. 2002;62:437-450.

15. Sanborn AF, Noriega FG, Phillips PK. Thermoregulation in the cicada Platypedia putnami var. lutea with a test of a crepitation hypothesis. J Therm Biol. 2002;27:365-369.

16. Sanborn AF, Phillips PK, Villet MH. Thermal responses in some Eastern Cape African cicadas (Hemiptera: Cicadidae). J Therm Biol. 2003;28:347-351.

17. Sanborn AF. Thermoregulation and endothermy in the large western cicada Tibicen cultriformis (Hemiptera: Cicadidae). J Therm Biol. 2004;29:97-101.

18. Sanborn AF, Heath JE, Heath MS, Phillips PK. Temperature responses and habitat selection by mangrove cicadas in Florida and Queensland (Hemiptera Cicadoidea). Trop Zool. 2004;17:65-72.

19. Sanborn AF, Heath MS, Heath JE, Noriega FG, Phillips PK. Convergence and parallelism among cicadas of Argentina and the southwestern United States (Hemiptera: Cicadoidea). Biol J Linn Soc Lond. 2004;83:281-288.

20. Heath MS, Sanborn AF. A new species of cicada of the genus Okanagana (Hemiptera: Cicadoidea: Cicadidae) from Arizona. Ann Entomol Soc Am. 2007;100:483-489. 
21. Marlatt CL. A new nomenclature for the broods of the periodical cicada. Bul USDA Div Entomol. 1898;18:5258.

22. Williams KS, Simon C. The ecology, behavior, and evolution of periodical cicadas. Annu Rev Entomol. 1995;40:269-295.

23. Sanborn AF. Periodical cicadas: The magic cicada (Hemiptera, Tibicinidae, Magicicada spp.). Denisia. 2002;4:225-230.

24. Rank NE, Dahlhoff EP. Allele frequency shifts in response to climate change and physiological consequences of allozyme variation in a montane insect. Evolution. 2002;56:2278-2289.

25. Greenberg AJ, Moran JR, Coyne JA, Wu CI. Ecological adaptations during incipient speciation revealed by precise gene replacement. Science. 2003;302:1754-1757.

26. Tauber E, Zordan M, Sandrelli F, et al. Natural selection favors a newly derived timeless allele in Drosophila melanogaster. Science. 2007;316:1895-1898.
27. Huestis DL, Oppert B, Marshall JL. Geographic distributions of $I d h-1$ alleles in a cricket are linked to differential enzyme kinetic performance across thermal environments. BMC Evol Biol. 2009;9:113.

28. Takeuchi KI, Nakano Y, Kato U, et al. Changes in temperature preferences and energy homeostasis in dystoglycan mutants. Science. 2009;323:1740-1743.

29. Heath JE. Behavioral regulation of body temperature in poikilotherms. Physiologist. 1970;13:399-410.

30. Sanborn AF, Perez LM, Valdes CG, Seepersaud AK. Wing morphology and minimum flight temperature in cicadas (Insecta: Homoptera: Cicadoidea). FASEB J. 2001;15:A1106.

\section{Publish your work in this journal}

Open Access Insect Physiology is an international, peer-reviewed, open access journal publishing original research, reports, reviews and commentaries on all areas of insect physiology. The manuscript management system is completely online and includes a very quick and fair peer-review system, which is all easy to use.

\section{Dovepress}

Visit http://www.dovepress.com/testimonials.php to read real quotes from published authors. 